\title{
Inhibition Effect of Eosin Y on Carbonic Anhydrase (CA) I and II Isoenzymes Purified from Human Erythrocytes
}

\author{
Zuhal ALIM ${ }^{1 *}$
}

\begin{abstract}
All cells produce carbon dioxide $\left(\mathrm{CO}_{2}\right)$, which is released as a result of metabolism and must be removed from the body. A large part of this $\mathrm{CO}_{2}$ is converted to bicarbonate by the carbonic anhydrase (CA) enzyme in erythrocytes and is discarded from the body. So, CA has a vital role in red blood cells. In addition to, CA involved in many other pathological and physiological processes and it was determined that the inhibitors of CA were effective in the treatment and diagnosis of many diseases particularly glaucoma. Considering the importance of the CA's inhibitors, in this study it was intended to research the inhibition effects of Eosin Y on CA I and CA II isoenzymes activity purified from human erythrocytes. Eosin Y is a dye molecule commonly used in histological and medical applications. For this purpose, firstly CA I and CA II isoenzymes were purified from human erythrocytes by using Sepharose-4B-L-tyrosine-sulfanilamide affinity chromatography. Then the inhibitory effect of Eosin Y on the activity of these human erythrocyte CA I (hCA I) and CA II (hCA II) isoenzymes was investigated. It was determined that hCA I and hCA II were inhibited by Eosin Y in the millimolar range. $\mathrm{IC}_{50}$ values were found to be $3.78 \mathrm{mM}$ for hCA I and $2.04 \mathrm{mM}$ for hCA II and $\mathrm{K}_{\mathrm{i}}$ values were determined as $9.65 \pm 0.968 \mathrm{mM}$ and $7.52 \pm 2.88 \mathrm{mM}$ for hCA I and hCA II, respectively. In conclusion, it is hoped that the results obtained in this study may be beneficial in the development of new CA inhibitors which may be drug candidates.
\end{abstract}

Keywords: Human erythrocyte, carbonic anhydrase, eosin Y, inhibition.

\section{İnsan Eritrositlerinden Saflaştırılan Karbonik Anhidraz (CA) I ve II İzoenzimleri Üzerinde Eozin Y'nin İnhibisyon Etkisi}

ÖZET: Bütün hücrelerde metabolizma sonucu açığa çıkan ve vücuttan atılması gereken karbondioksit üretilir. $\mathrm{Bu} \mathrm{CO}{ }_{2}$ 'nin büyük bir kısmı eritrositlerde $\mathrm{CA}$ enzimi tarafından bikarbonata dönüştürülür ve vücuttan atılır. $\mathrm{Bu}$ nedenle, CA'nın kırmızı kan hücrelerinde hayati bir rolü vardır. Ayrıca, CA diğer birçok patolojik ve fizyolojik süreçlere dahil olmuştur ve CA inhibitörlerinin, özellikle glokom gibi birçok hastalığın tedavisinde ve tanısında etkili olduğu belirlenmiştir. CA inhibitörlerinin önemi göz önüne alındığında, bu çalışmada Eosin Y'nin insan eritrositlerinden saflaştırılmış CA I ve CA II izoenzimlerin aktivitesi üzerindeki inhibisyon etkilerinin araştırılması amaçlanmıştır. Eozin Y, histolojik ve tıbbi uygulamalarda yaygın olarak kullanılan bir boya molekülüdür. $\mathrm{Bu}$ amaçla öncelikle CA I ve CA II izoenzimleri, Sepharose-4B-L-tirozin-sülfanilamid afinite kromatografısi kullanılarak insan eritrositlerinden saflaştırıldı. Daha sonra, Eozin Y'nin bu insan eritrosit CA I (hCA I) ve CA II (hCA II) izoenzimlerinin aktivitesi üzerindeki inhibitör etkisi araştırıldı. hCA I ve hCA II'nin millimolar aralıktaki Eozin Y tarafindan inhibe edildiği belirlendi. IC $_{50}$ değerleri hCA I için 3,78 mM ve hCA II için 2,04 mM. $\mathrm{K}_{\mathrm{i}}$ değerleri ise hCA I ve hCA II için sırasıyla $9,65 \pm 0,968 \mathrm{mM}$ ve 7,52 $\pm 2,88 \mathrm{mM}$ olarak tespit edildi. Sonuç olarak, bu çalışmada elde edilen sonuçların, ilaç adayı olabilecek yeni CA inhibitörlerinin geliştirilmesinde faydalı olacağı ümit edilmektedir.

Anahtar kelimeler: İnsan eritrositi, karbonik anhidraz, eozin Y, inhibisyon.

${ }^{1}$ Zuhal ALIM (Orcid ID: 0000-0003-1977-1756), Kırşehir Ahi Evran Üniversitesi, Fen Edebiyat Fakültesi, Kimya Bölümü, Kırşehir, Türkiye

*Sorumlu Yazar/Corresponding Author: Zuhal ALIM, e-mail: zuhal.alim@ahievran.edu.tr

Geliş tarihi / Received: 18-07-2019

Kabul tarihi / Accepted: 16-09-2019 


\section{INTRODUCTION}

Carbonic anhydrases (CAs, EC 4.2.1.1) are zinc-content $\left(\mathrm{Zn}^{2+}\right)$ metalloproteins included in the lyase class and catalyses carbon dioxide $\left(\mathrm{CO}_{2}\right)$ conversion to bicarbonate $\left(\mathrm{HCO}_{3}{ }^{-}\right)$and proton $\left(\mathrm{H}^{+}\right)$ reversibly (Alterio et al., 2012; Aksu et al., 2013; Aslan et al., 2019). The most fundamental function of carbonic anhydrase is respiratory and is responsible for $\mathrm{CO}_{2}$ /bicarbonate transport in various metabolised tissues (Kaya et al., 2019; Türkeş et al., 2019). In addition, CA acts on CA many important physiological functions from $\mathrm{pH}$ regulation to biosynthesis reactions (gluconeogenesis, lipogenesis, urogenesis etc.) (Alim et al., 2015). Numerous scientific studies have been conducted on CA isoenzymes due to their important physiological functions (Caglayan et al., 2018; Caglayan et al., 2019). Since CAs are closely related to many diseases such as glaucoma (Juncal et al., 2013), edema (Wolfensberger, 1999), osteoporosis (Mori et al., 2009), obesity (Scozzafava et al., 2013), ulcer (Buzas and Supuran, 2016), cancer (Benej et al., 2014), epilepsy and other neurological disorders (Jang et al., 2010; Aggarwal et al., 2013), CAs have become a therapeutic target molecule especially in drug design studies. Because of its physiological importance, the identification of activators and inhibitors of CAs has been a strong target for drug development studies (Erdemir et al., 2019; Saglık et al., 2019). Currently inhibitors of CAs are widely used as drug in the treatment of many diseases such as glaucoma, epilepsy, ulcer, cancer, obesity, edema (Supuran, 2011). On the other hand, nowadays CA activators are evaluated as potential pharmacological agents in Alzheimer's disease, ageing and other neurological disorders. Recent studies have shown that the $\mathrm{HCO}_{3}{ }^{-}$concentration is increased rapidly and efficiently in the memory-related nerve structures with the activation of the carbonic anhydrase enzyme. Therefore, it has been determined that the CA plays an significant role in nervous system.

So, CA malfunction is closely related to mental retardation, Alzheimer's and other neurodegenerative diseases. Scientists therefore thought that CA activators would provide a new method of treatment for Alzheimer's and other mental disorders (Sun and Alkan, 2002; Supuran, 2008).

To date, $16 \mathrm{CA}$ isoenzymes with significant physiological roles have been identified, and among them CA I and CA II are the most widely studied and they are two main isoenzymes found in mammalian erythrocytes (Ekinci et al., 2007). CA I is the most abundant protein in erythrocytes, but also in the gastrointestinal tract. CA II, which has the highest turnover ratio, shows widespread distribution in almost all tissues and organs together with erythrocytes. CA I and CA II participate in important metabolic functions and are closely related to many diseases (Hu et al., 1992; Hassan et al., 2013). Therefore, the determination of these two isoenzyme inhibitors is very important. For example, inhibition of CA II reduces intraocular pressure which damages the optic nerve of the eye in gluocoma (Supuran et al., 2001). Therefore, inhibitors of CA II are drug candidate for glaucoma disease. In addition, recent studies have indicated that CA I and CA II inhibitors can be used as important biomarkers in some cancer diseases.

Carbonic anhydrase inhibitors are divided into two main classes according to enzyme binding sites. The first is those that are interact directly with the catalytic zinc ion. The second is the ones that are not directly affected by the zinc ion and are connected to the active site (Chiaramonte et al., 2018). Since there are 16 isoenzymes of the carbonic anhydrase enzyme, most CA inhibitors are non-specific and have numerous side effects. (Alım, 2018). In order to prevent this, inhibitors specific to isoenzymes need to be designed. Therefore, studies on the development of inhibitory derivatives which show selective inhibition effect against CA isoenzymes are very important.

Eosin $\mathrm{Y}$ is an acidic dye that binds to the essential components of the cell, and in particular to proteins in the cytoplasm. Eosin $\mathrm{Y}$ is chemically known as disodium 2-(2, 4, 5, 7-tetrabromo-6-oxido3-oxo-3H-xanthen-9-yl) benzoate have a molecular formula $\left(\mathrm{C}_{20} \mathrm{H}_{6} \mathrm{Br}_{4} \mathrm{Na}_{2} \mathrm{O}_{5}\right)$. Combination of Eosin $\mathrm{Y}$ with hematoxylin is the most common staining and primary diagnostic technique used in histopathological studies. Eosin Y is also one of the most common ion-coupling agents, and its mono and di-anionic forms can interact with many drug molecules (Waheed et al., 2000; Rahman, 2017). The aim of this study was to investigate the inhibitory effect of Eosin Y on CA I and CA II isoenzymes of human erythrocytes. 


\section{MATERIALS and METHODS}

\section{Chemicals}

All chemicals used in purification processes and kinetic studies were purchased from SigmaAldrich Co. (Steinheim, Germany).

\section{Purification Process of CA I and CA II From Human Erythrocytes}

Sepharose-4B-L-tyrosine-sulfanilamide affinity column was prepared to purify the CA I and CA II isoenzymes from human erythrocytes. The affinity column was equilibrated using $25 \mathrm{mM}$ Tris- $\mathrm{HCl} /$ $0.1 \mathrm{M} \mathrm{Na}_{2} \mathrm{SO}_{4}(\mathrm{pH}$ 8.7) buffer solution. Preparation of human erythrocyte hemolysate (40 mL) and purification of CAI and CAII were done as in previous study (Alım, 2018). During the purification, the elution of CA I and CA II was monitored by measuring the absorbance at $280 \mathrm{~nm}$. CA I and CA II activity in the eluates were measured by the hydratase activity measurement method determined by Wilbur-Anderson (Wilbur and Anderson, 1948). The active enzyme fractions were collected and dialyzed against $0.05 \mathrm{M}$ Tris-SO $\mathrm{SO}_{4}(\mathrm{pH}$ 7.4) buffer overnight. After dialysis, CA I and CA II isoenzymes were stored at $-80{ }^{\circ} \mathrm{C}$ in small fractions for use in subsequent kinetic studies. The amount of protein in the hemolysate and the purified CA I and CA II enzyme solutions was determined using the Bradford method (Bradford, 1976). The purity control of the isoenzymes was performed by SDS-PAGE determined by Laemmli (Laemmli, 1970).

\section{Biological Activity Assay}

The activity of $\mathrm{CA}$ isoenzymes in inhibition studies was measured by the esterase activity described by Verpoorte et al. (Verpoorte et al., 1967). The activity of isoenzymes according to this method was measured at $348 \mathrm{~nm}$ formation of 4-nitrophenylate from 4-nitrophenylacetate for $3 \mathrm{~min}$ at $25{ }^{0} \mathrm{C}$ using a spectrophotometer. Activity measurements were performed using at least 5 different concentrations of Eosin Y molecule. In the absence of Eosin Y molecule, the control activity of the CA I and CA II isoenzymes is assumed to be $100 \%$. Measurement results are plotted as \% Activity/[Inhibitor Concentration] graphs. The $\mathrm{IC}_{50}$ value was calculated for Eosin $\mathrm{Y}$ molecule from these graphs. To determine the inhibition type of Eosin Y molecule, activity measurements were performed at 3 different inhibitor concentrations and 5 different substrate concentrations. Lineweaver-Burk graphs $(1 / \mathrm{V}-1 /[\mathrm{S}])$ (Lineweaver and Burk, 1934) were drawn with measurement results. For hCA I and hCA II, $\mathrm{K}_{\mathrm{i}}$ values of the Eosin Y were determined from these graphs.

\section{RESULT and DISCUSSION}

CA is a vital enzyme that enables the organism to regulate the acid-base balance (Topal et al., 2014; Demir et al., 2016). It is one of the most important buffer systems in the human body (Deitmer et al., 2014). CA participates in many important physiological events such as the regulation of cardiovascular tone, ion exchange between cell divisions, and the provision of bicarbonate for various enzymatic reactions, as well as providing acid-base balance (Vaughan-Jones and Spitzer, 2002). CA inhibitors and activators are therefore clinically important compounds.

Considering the importance of CA inhibitors, in this study, it was examined the inhibition effect of eosin Y, which is commonly used in histological studies, on hCA I and hCA II. Eosin is a fluorescent acidic compound that binds to compounds such as proteins containing amino acid residues of arginine and lysine and stain them dark red or pink under the action of bromine. Eosin $\mathrm{Y}$ is the most widely used form of eosin in histology. In addition, Eosin Y is also one of the most common ion-coupling agents, and its mono and di-anionic forms can interact with many drug molecules. Therefore, it belongs to the xanthan dye group, which is widely used in the analysis of many drugs (Waheed et al., 2000; Rahman, 2017). In this study, in order to investigate the inhibitory effects of eosin Y on hCA I and hCA II isoenzymes, firstly, CA I and CA II isoenzymes were purified from human erythrocytes and the purification table was prepared with the data obtained (Table 1). The elution graph was shown in Figure 1A. The purity of the enzyme was checked by SDS-PAGE (Figure 1B). 
Table 1. Purification results of hCA I and hCA II isoenzymes from human erythrocytes

\begin{tabular}{ccccccccc}
\hline $\begin{array}{c}\text { Purification } \\
\text { Steps }\end{array}$ & $\begin{array}{c}\text { Activity } \\
(\mathbf{E U} / \mathbf{m l})\end{array}$ & $\begin{array}{c}\text { Total } \\
\text { Volume } \\
(\mathbf{m l})\end{array}$ & $\begin{array}{c}\text { Protein } \\
(\mathbf{m g} / \mathbf{m l})\end{array}$ & $\begin{array}{c}\text { Total } \\
\text { Protein } \\
(\mathbf{m g})\end{array}$ & $\begin{array}{c}\text { Total } \\
\text { Activity } \\
(\mathbf{E U})\end{array}$ & $\begin{array}{c}\text { Specific } \\
\text { Activity } \\
(\mathbf{E U} / \mathbf{m g})\end{array}$ & $\begin{array}{c}\text { Yield } \\
(\boldsymbol{\%})\end{array}$ & $\begin{array}{c}\text { Purification } \\
\text { factor }\end{array}$ \\
\hline Hemolysate & 250 & 25 & 28.16 & 704 & 6250 & 8.877 & 100 & 1 \\
hCA I & 480 & 10 & 1.025 & 10.25 & 4800 & 468.292 & 76.8 & 52.75 \\
hCA II & 925 & 6 & 0.182 & 1.092 & 5550 & 5082.417 & 88.8 & 572.54 \\
\hline
\end{tabular}

A

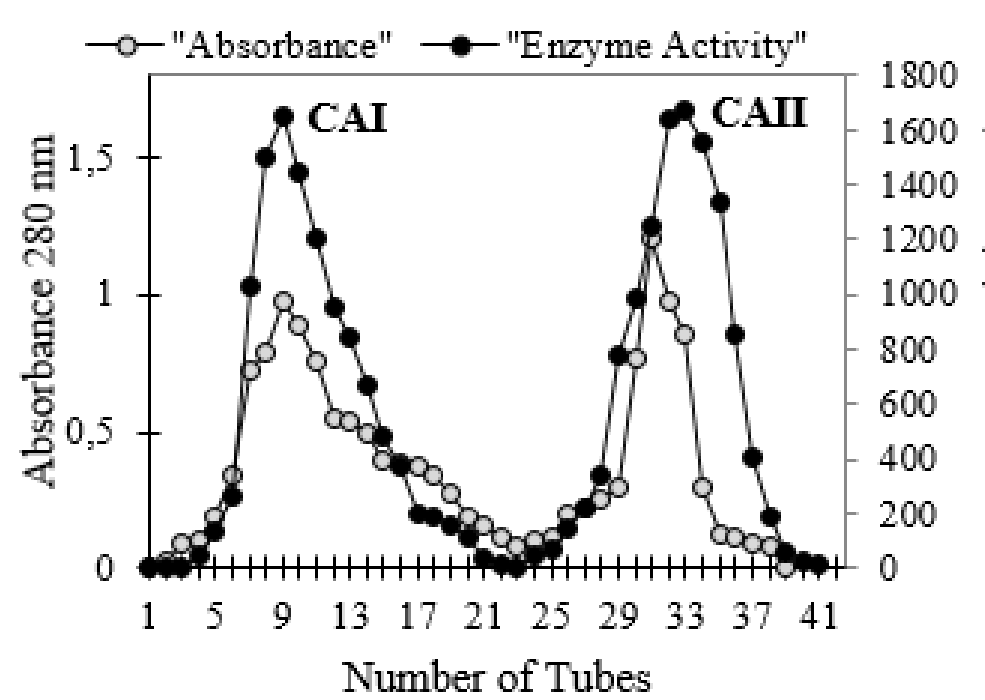

B

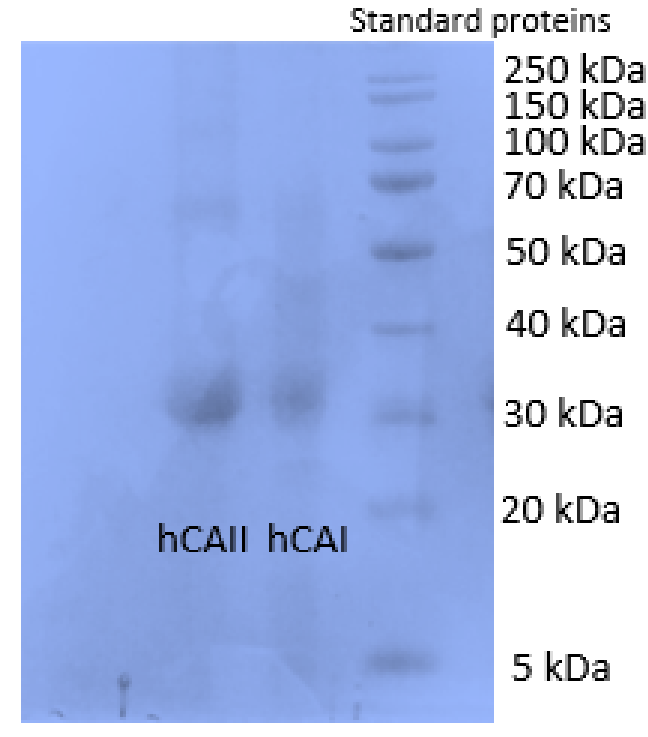

Figure 1. The elution graph of hCA I and hCA II (A) and SDS-PAGE photo showing the purity of isoenzymes (B)

After purification, it was examined the inhibitory effect of Eosin Y on the pure hCA I and hCA II. Eosin Y exhibited inhibition effect at low concentrations on hCA I and hCA II. Activity\% versus inhibitor concentration was plotted (Figure 2A, 2C). Using these \%Activity/[Inhibitor concentration] graphs, $\mathrm{IC}_{50}$ values were determined as $3.78 \mathrm{mM}$ and $2.04 \mathrm{mM}$ for hCA I and hCA II, respectively. According to these results, Eosin $\mathrm{Y}$ is a more potent inhibitor for hCA II. To determine the inhibition type and $\mathrm{K}_{\mathrm{i}}$ of Eosin $\mathrm{Y}$, Lineweaver-Burk graphs were drawn (Figure 2B, 2D).

$\mathrm{K}_{\mathrm{i}}$ values and inhibition types for hCA I and hCA II isoenzymes of Eosin Y was determined from these graphs. $K_{i}$ values were determined as $9.65 \pm 0.968 \mathrm{mM}$ and $7.52 \pm 2.88 \mathrm{mM}$ for hCA I and hCA II, respectively. The low $\mathrm{K}_{\mathrm{i}}$ constant indicates that the inhibitor has a strong binding affinity to the enzyme. According to our results, the binding affinity of Eosin Y to hCA II was higher than hCA I. Eosin Y showed noncompetitive inhibition effect for both isoenzymes (Table 2).

Table 2. $\mathrm{IC}_{50}$ values and $K_{i}$ constants of Eosin $\mathrm{Y}$

\begin{tabular}{ccccccc}
\hline Compound & \multicolumn{3}{c}{ hCA I } & \multicolumn{2}{c}{ hCA II } \\
\cline { 2 - 7 } Eosin Y & $\mathrm{IC}_{50}(\mathrm{mM})$ & $\mathrm{K}_{\mathrm{i}}(\mathrm{mM})$ & Inhibition Type & $\mathrm{IC}_{50}(\mathrm{mM})$ & $\mathrm{K}_{\mathrm{i}}(\mathrm{mM})$ & Inhibition Type \\
\hline
\end{tabular}

According to this result, The carboxylic and phenolic groups of Eosin Y may be electrostatically bound to amino acids outside the active sites of the hCA I and hCA II isoenzymes, causing a reduction in the catalytic activity of the isoenzymes. Because studies have indicated that carboxylic and phenolic groups of Eosin $\mathrm{Y}$ is electrostatically bound to the tryptophan residue of proteins at acidic $\mathrm{pH}$ and to arginine, histidine and lysine residues at both acidic and neutral $\mathrm{pH}$ (Waheed et al., 2000). 


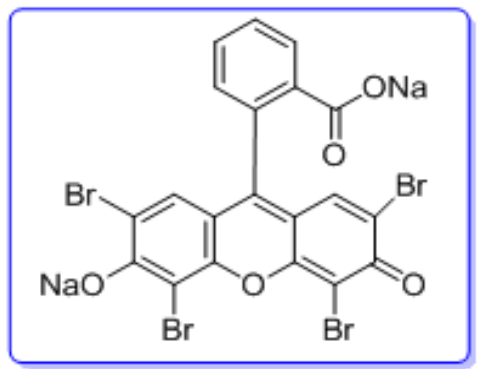

$\operatorname{Eosin} \mathrm{Y}$
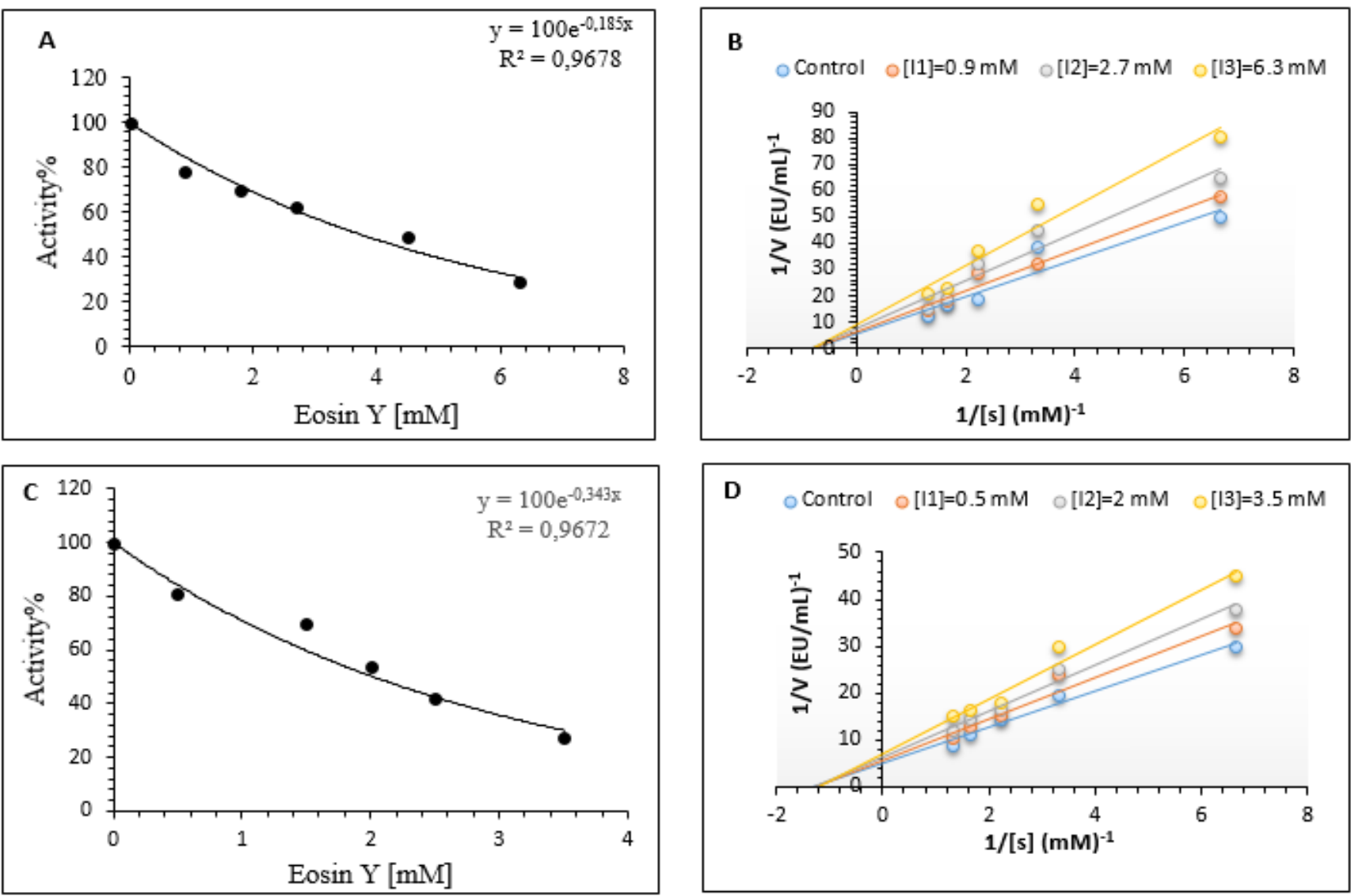

Figure 2. $\mathrm{IC}_{50}$ graphs $(\mathrm{A}, \mathrm{C})$ and Lineweaver-Burk graphs $(\mathrm{B}, \mathrm{D})$ of Eosin Y for hCA I and hCA II, respectively

\section{CONCLUSION}

In conclusion, Eosin Y, the most commonly used xanthan dye in histological and drug analysis studies (Rahman, 2017), showed inhibition effect on hCA I and hCA II isoenzymes. Carbonic anhydrase inhibitors are drug candidates for the treatment of many diseases, from glaucoma to neuropathic pain (Supuran, 2018). It is hope that the results obtained in this study may be beneficial in the development of new carbonic anhydrase inhibitors which may be drug candidates.

\section{REFERENCES}

Aggarwal M, Kondeti B, McKenna R, 2013. Anticonvulsant/antiepileptic carbonic anhydrase inhibitors: a patent review. Expert Opinion on Therapeutic Patents, 23 (6): 717-724.

Aksu K, Nar M, Tanç M, Vullo D, Gulcin I, Göksu F, Tümer F, Supuran CT, 2013. The synthesis of sulfamide analogues of dopamine related compounds and their carbonic anhydrase inhibitory properties. Biorganic Medicinal Chemistry, 21 (11): 2925-2931. 
Alım Z, Kilinc N, Sengul B, Beydemir S, 2015. Some Anti-Inflammatory Agents Inhibit Esterase Activities of Human Carbonic Anhydrase Isoforms i and II: An in Vitro Study. Chemical Biology and Drug Design, 86 (4): 857-863.

Alım Z, 2018. 1H-indazole molecules reduced the activity of human erythrocytes carbonic anhydrase I and II isoenzymes. Journal of Biochemical and Molecular Toxicology, 32 (9): e22194.

Alterio V, Di Fiore A, D'Ambrosio K, Supuran CT, De Simone G, 2012. Multiple binding modes of inhibitors to carbonic anhydrases: how to design specific drugs targeting 15 different isoforms. Chemical Reviews, 112 (8): 4421-4468.

Aslan HE, Demir Y, Özaslan MS, Türkan F, Beydemir Ş, Küfrevioğlu ÖI. 2019. The behavior of some chalcones on acetylcholinesterase and carbonic anhydrase activity. Drug and Chemical Toxicology, 42(6):634-640.

Benej M, Pastorekova S, Pastorek J, 2014. Carbonic anhydrase IX: regulation and role in cancer. Subcellular Biochemistry, 75: 199-219.

Bradford MM, 1976. A rapid and sensitive method for the quantitation of microgram quantities of protein utilizing the principle of protein-dye binding. Analytical biochemistry, 72 (1-2): 248-251.

Buzas GM, Supuran CT, 2016. The history and rationale of using carbonic anhydrase inhibitors in the treatment of peptic ulcers. In memoriam Ioan Puşcaş (1932-2015). Journal of Enzyme Inhibition Medicinal Chemistry, 31 (4): 527-533.

Caglayan C, Taslimi P, Demir Y, Küçükler S, Kandemir, FM, Gülcin I. 2019. The effects of zingerone against vancomycin-induced lung, liver, kidney and testis toxicity in rats: The behavior of some metabolic enzymes. Journal of Biochemical and Molecular Toxicology, e22381. https://doi.org/10.1002/jbt.22381

Caglayan C, Demir Y, Küçükler S, Taslimi P, Kandemir, FM, Gülcin I. 2018. The effects of hesperidin on sodium arsenite-induced different organ toxicity in rats on metabolic enzymes as antidiabetic and anticholinergics potentials: A biochemical approach. Journal of Food Biochemistry, 43(2): e 12720.

Chiaramonte N, Romanelli MN, Teodori E, Supuran CT, 2018. Amino Acids as Building Blocks for Carbonic Anhydrase Inhibitors. Metabolites, 8(2): 36.

Ekinci D, Beydemir S, Alim Z, 2007. Some drugs inhibit in vitro hydratase and esterase activities of human carbonic anhydrase-I and II. Pharmacological Reports, 59(5): 580-587.

Erdemir F, Celepci DB, Aktaş A, Gök Y, Kaya R, Taslimi P, Demir Y, Gulçin İ. 2019. Novel 2-aminopyridine liganded $\mathrm{Pd}(\mathrm{II}) \mathrm{N}$-heterocyclic carbene complexes: Synthesis, characterization, crystal structure and bioactivity properties. Bioorganic Chemistry, 91:103134.

Deitmer JW, Theparambil SM, Ruminot I, Becker HM, 2014. The role of membrane acid/base transporters and carbonic anhydrases for cellular $\mathrm{pH}$ and metabolic processes. Front Neuroscience, 8: 430.

Demir Y, Oruç E, Topal A. 2016. Carbonic anhydrase activity responses and histopathological changes in gill and liver tissues after acute exposure to chromium in brown trout juveniles. Hacettepe Journal of Biology and Chemistry 44:515-523.

Hassan I, Shajee B, Waheed A, Ahmad F, Sly WS, 2013. Structure, function and applications of carbonic anhydrase isozymes. Bioorganic \& Medicinal Chemistry, 21 (6), 1570-1582.

Hu PY, Roth DE, Skaggs LA, Venta PJ, Tashian RE, Guibaud P, Sly WS, 1992. A splice junction mutation in intron 2 of the carbonic anhydrase II gene of osteopetrosis patients from Arabic countries. Human Mutation, 1(4): 288-292.

Jang BG, Yun SM, Ahn K, Song JH, Jo SA, Kim YY, Kim DK, Park MH, Han C, Koh YH, 2010. Plasma carbonic anhydrase II protein is elevated in Alzheimer's disease. Journal of Alzheimer's Disease, 21 (3): 939-945.

Juncal VR, Abdo JF, Paranhos AJ, Santos PT, 2015. Carbonic anhydrase inhibitors as fourth drug in primary glaucomas: Is it worth it? Canadian Journal of Ophthalmology, 50(4): 297-301.

Laemmli UK, 1970. Cleavage of structural proteins during the assembly of the head of bacteriophage T4. Nature, 227 (5259): 680-685.

Kaya ED, Ergun B, Demir Y, Alım Z, Beydemir S. 2019. The In Vitro Impacts of Some Plant Extracts on Carbonic Anhydrase I, II and Paraoxonase-1. Hacettepe Journal of Biology and Chemistry, 47(1):51-59. 
Lineweaver H, Burk D, 1934. The determination of enzyme dissociation constants. Journal of the American chemical society, 56 (3): 658-666.

Mori S, Kou I, Sato H, Emi M, Ito H, Hosoi T, Ikeqawa S, 2009. Nucleotide variations in genes encoding carbonic anhydrase 8 and 10 associated with femoral bone mineral density in Japanese female with osteoporosis. Journal of Bone and Mineral Metabolism. 27 (2): 213-216.

Wolfensberger TJ, 1999. The role of carbonic anhydrase inhibitors in the management of macular edema. Documenta Ophthalmologica, 97 (3-4): 387-397.

Rahman H, 2017. Utilization of eosin dye as an ion pairing agent for determination of pharmaceuticals: A brief review. International Journal of Pharmacy and Pharmaceutical Sciences, 9 (12):1-9

Sağlık BN, Çevik UA, Osmaniye D, Levent S, Çavuşoğlu BK, Demir Y, Ilgın S, Özkay Y, Koparal AS, Beydemir Ş, Kaplanciklı ZA. 2019. Synthesis, molecular docking analysis and carbonic anhydrase I-II inhibitory evaluation of new sulfonamide derivatives. Bioorganic Chemistry, 91:103153.

Scozzafava A, Supuran CT, Carta F, 2013. Antiobesity carbonic anhydrase inhibitors: a literature and patent review. Expert Opinion on Therapeutic Patents, 23 (6): 725-735.

Sun MK, Alkon DL, 2002. Carbonic anhydrase gating of attention: memory therapy and enhancement. Trends in Pharmacological Sciences, 23 (2): 83-89.

Supuran CT, Briganti F, Tilli S, Chegwidden WR, Scozzafava A, 2001. Carbonic anhydrase inhibitors: sulfonamides as antitumor agents? Bioorganic Medicinal Chemistry, 9(3): 703-14.

Supuran CT, 2008. Carbonic anhydrases: novel therapeutic applications for inhibitors and activators. Nature Reviews Drug Discovery, 7(2): 168-181.

Supuran CT, 2011. Carbonic anhydrase inhibitors and activators for novel therapeutic applications. Future Medicinal Chemistry, 3 (9):1165-1180.

Supuran CT, 2018. Carbonic anhydrase activators. Future Medicinal Chemistry, 10(5):561-573.

Taslimi P, Kandemir, FM, Demir Y, İleritürk M, Temel Y, Caglayan C, Gülcin I. 2019. The Antidiabetic and Anticholinergic Effects of Chrysin on Cyclophosphamide-Induced Multiple Organs Toxicity in Rats: Pharmacological Evaluation of Some Metabolic Enzymes Activities. Journal of Biochemical and Molecular Toxicology, 33(6):e22313.

Topal A, Atamanalp M, Oruç E, Demir Y, Beydemir Ş, Işık A. 2014. In vivo changes in carbonic anhydrase activity and histopathology of gill and liver tissues after acute exposure to chlorpyrifos in rainbow trout. Archives of Industrial Hygiene and Toxicology, 65(4) 377-385.

Türkeş C, Arslan M, Demir Y, Çoçaj L, Rifati Nixha A, Beydemir Ş. 2019. Synthesis, biological evaluation and in silico studies of novel N-substituted phthalazine sulfonamide compounds as potent carbonic anhydrase and acetylcholinesterase inhibitors. Bioorganic Chemistry, 89:103004.

Vaughan-Jones RD, Spitzer KW, 2002. Role of bicarbonate in the regulation of intracellular pH in the mammalian ventricular myocyte. Biochemistry and Cell Biology, 80 (5): 579-596.

Verpoorte JA, Mehta S, Edsall JT, 1967. Esterase activities of human carbonic anhydrases B and C. The Journal of Biological Chemistry, 242 (18): 4221-4229.

Wilbur KM, Anderson NG, 1948. Electrometric and colorimetric determination of carbonic anhydrase. The Journal of Biological Chemistry, 176(1): 147-154.

Waheed AA, Rao Sridhar K, Gupta PD, 2000. Mechanism of Dye Binding in the Protein Assay Using Eosin Dyes. Analytical Biochemistry, 287 (1): 73-79. 